\title{
Assessment of winter oilseed rape DH lines using uni- and multivariate methods of quantitative genetics and mathematical methods
}

\author{
Laurencja SzaŁa $^{1 *}{ }^{*}$ Zygmunt KaczmareK $^{2}{ }^{2}$ Elżbieta Adamska ${ }^{2}$, Teresa Cegielska-Taras ${ }^{1}$ \\ ${ }^{1}$ Plant Breeding and Acclimatization Institute - National Research Institute, Research Division in Poznań, Poznań, Poland \\ ${ }^{2}$ Institute of Plant Genetics, Polish Academy of Sciences, Poznań, Poland \\ *Corresponding author: 1szala@nico.ihar.poznan.pl
}

\begin{abstract}
The development and improvement of an in vitro androgenesis of oilseed rape has allowed to obtain doubled haploid (DH) populations on a large scale. It has become possible to use $\mathrm{DH}$ lines in a genetic analysis of quantitative traits. Among the other benefits of DHs, homozygous state allowed to use them in a series of experiments aiming at the efficient selection of desired genotypes and their examination for adaptation in various environments. This is a review of our earlier studies which have confirmed numerous possibilities of using winter oilseed rape DH lines in a statistical analysis. Populations of DHs were used for: estimation of genetic parameters, transgression effects as well as a general and specific combining ability, genetic variation in $\mathrm{DH}$ populations or effects of the cross direction. In this paper, possibilities of a comprehensive multidirectional assessment of DHs lines of oilseed rape through the application of uni- and multivariate methods of quantitative genetics and mathematical methods are also presented.
\end{abstract}

Keywords: Brassica napus L., doubled haploids, uni- and multivariate methods, transgression, genetic variation

\section{Introduction}

The development and improvement of the process of the in vitro androgenesis of oilseed rape enables doubled haploid (DH) populations to be obtained on a larger scale, facilitating both the application of $\mathrm{DH}$ lines in the genetic analysis of quantitative traits and the research into the impact of the environment on the yield and quality of the seed. Because of its homozygosity, a single DH line produces only one type of gamete which, in controlled conditions, duplicates its own genotype. This allows to perform multiple experiments with the same genotype, in various locations and different years, which is not possible with a generation of segregated hybrids in classical breeding. Moreover, for traits controlled by polygenic inheritance, the $\mathrm{DH}$ technology requires fewer genotypes, because there are no heterozygotes; thus, no dominance effects, and no interactions of non-allelic heterozygous loci can be observed.

\section{Estimation of genetic parameters}

The knowledge of effects of expression of genes controlling quantitative traits enables to choose the strategy of breeding. One of the methods to obtain this information is the estimation of the genetic parameters.

A series of field experiments were carried out on 32 DH lines of winter oilseed rape, their parental forms (DH C-1041, DH O-120) and F2 and F3 hybrids to evaluate genetic parameters controlling yield components. Such parameters may include the oil content and fatty acids in oil, the number of genes or closely linked gene clusters needed to control the content of these acids. Based on the DH lines and respective segregating generations, the genetic parameters determining the effects of the additive gene action, domination and the non-allelic interaction of homozygous and heterozygous loci were estimated for the length of pods, the number of seeds per pod, 1000 seeds weight and the oil content (Adamska et al., 2002). The effects of the additive gene action were significant for each studied trait. The dominance was significant only for the length of pod and the number of seeds per pod. The effect of heterozygous gene action was not observed in this study. Genetic parameters for individual fatty acids content in oil were described by Cegielska-Taras et al. (2005). The effects of the additive gene action calculated for every year separately and 
jointly for three years were significant for all the analyzed fatty acids. The effects of the interaction between the homozygous loci positively influenced the increase in the oleic acid content. The dominance effects were observed from a three-year experiment, only for the palmitic acid (Cegielska-Taras et al., 2005). The effects of nonallelic interactions of heterozygous loci were insignificant for the content of all studied acids in all years.

\section{Estimation of transgression effects}

Due to their homozygosity, DH lines are excellent material for the investigation of the occurrence of transgression effects. The most common explanation of that phenomenon is that transgression is the result of a complementary gene action. The frequency of occurrence of transgressive genotypes depends, above all, on the genetic differentiation of parental components and their phenotypic similarity. In homozygous populations, the lines that are significantly better than the higher-scoring parent, or significantly worse than the lower-scoring parent in respect of a given trait are considered transgressive (Kuczyńska et al., 2007). In the case of a great number of DH line populations and a small number of seeds only an unreplicated experiment with a replicated standard gives a possibility to estimate all genotypes. Kaczmarek et al. (2009) proposed statistical methods for both a phenotypic and genetic analysis and the estimation of the transgression effects of winter oilseed $\mathrm{DH}$ lines evaluated in unreplicated experiments. The statistical methods were described based on the example of the data obtained for fat content and for the thousand seed weight from an unreplicated experiment including 210 $\mathrm{DH}$ lines with parental forms as standards. The application of these methods, especially the method of contrasts, enabled selection of transgressive DH lines by subsequent unreplicated experiments carried out with regularly distributed standards - two parental forms.

Two populations of $\mathrm{DH}$ lines of winter oilseed rape obtained from $\mathrm{F} 1$ hybrids from the reciprocal cross cv. Californium and DH W-15 were studied concerning the number of branches per plant, the number of pods per plant, the number of seeds per pod, and the content of unsaturated $\mathrm{C} 18$ acids and glucosinolates. From among 210 studied DH lines, 26 DH lines exhibited positive transgression effects. The highest number of transgressive lines was recorded for the number of pods per plant (Szała et al., 2009a).
A total of $178 \mathrm{DH}$ lines obtained from $\mathrm{F} 1$ hybrids of the reciprocal crosses between yellow-seeded DH Z-114 and black-seeded $\mathrm{DH} \mathrm{H}_{2}-26$ were studied with regard to the occurrence of transgression effects - positive for protein, oleic acid, linoleic acid, and fat content and negative for content acid detergent fiber, neutral detergent fiber, linolenic acid, and glucosinolate content. The highest number of transgressive segregants was observed for oleic acid in oil and protein content (Szała et al., 2011).

\section{The general and specific combining ability}

DHs have been successfully used for commercial production of new cultivars of oilseed rape. The usefulness of $\mathrm{DH}$ lines in the breeding of new varieties depends on their combined values. A multidimensional approach was adopted for the investigation of the general and specific combining ability of $\mathrm{DH}$ lines (parental forms) of winter oilseed rape from experiments with $\mathrm{F} 1$ hybrids obtained from the line $\times$ tester mating design. The general combining ability (GCA) and specific combining ability (SCA) effects of seven different $\mathrm{DH}$ lines and four testers were estimated for the yield components and the fat content (Adamska et al., 2007) and for five saturated and unsaturated fatty acids such as palmitic, stearic, oleic, linoleic and linolenic acids (Adamska et al., 2008). Selected testers included a high-yielding winter oilseed rape (cv. Lisek), a DH line with short pods, a yellow-seeded DH line and a DH line with high oil content. A statistical analysis of DH lines made it possible to distinguish two lines with especially advantageous values for the number of seeds per pod, the number of branches and the number of pods per plant. In addition, three pairs of lines and testers with significant multidimensional SCA effects and at least three positive and significant effects of individual yield structure traits were identified. Two lines showed positive GCA effects for oleic acid content and one of them showed, simultaneously, significant and negative GCA effects for the linolenic acid content.

Another attempt was made to examine the relationship between the genetic distance of parental forms and their phenotypic diversity. This was assessed by the line $\times$ tester analysis (Szała et al., 2009b), while the genetic diversity of parental forms was estimated via molecular Random Amplified Polymorphic DNA (RAPD) markers. The assessment of the phenotypic differentiation of 
these forms was used to calculate the effects of heterosis, the GCA and SCA of the lines and testers and the Mahalanobis distances (Mahalanobis, 1936) between them.

There was a significant positive correlation between the genetic distance between the $\mathrm{DH}$ lines and the differences in the effects of GCA on the number of branches per plant. The relationship between the genetic distance between the lines and Mahalanobis distances proved to be significant for all genotypes (lines and testers) as well as for their corresponding Mahalanobis distances assigned to the six traits studied together.

\section{Genetic variation in DH populations}

DH lines are important source of a new genetic variation in the breeding of winter oilseed rape, which is a classic example of a species with a very narrow gene pool. If $\mathrm{F} 1$ hybrids are valuable, it is possible to count the desired segregation and recombination in gamete cells, and thereby obtain DH lines with agriculturally useful characteristics. Their adequate numbers can provide the greatest possible variability within the population resulting from a single hybrid. A significant variability can be obtained even in the case of haploidization of a cultivar, as evidenced by work on a $100 \mathrm{DH}$ lines derived from a winter oilseed rape cv. Bor (Szała et al., 2002). DH lines differed significantly in terms of 9 of the 11 studied traits (excluding plant height and the timing of the onset of flowering).

However, the highest variation in a population of the DH lines can be obtained from hybrids whose parental components are phenotypically diverse and which have different origins. This was the case for a mapping population of more than $300 \mathrm{DH}$ lines produced from an $\mathrm{F} 1$ hybrid resulting from crosses of high erucic acid and low glucosinolate content DH line ER-13/1 and zero erucic acid and high glucosinolate content DH line JN-86. As was revealed in a statistical analysis conducted for four morphological traits, the $\mathrm{DH}$ population developed to identify the quantitative trait loci (QTL) controlling the erucic acid and glucosinolate content was also characterized by a relatively high phenotypic variability (Szała et al., 2003).

The aim of the next study was to estimate the diversity of $\mathrm{DH}$ populations in terms of the yield, the yield structure, fat content and the levels of three fatty acids: oleic, linoleic and linolenic (Szała et al., 2013). This study was undertaken to determine if there was a correlation between the studied traits and their heritability, and to make clusters of the studied objects in terms of several traits together. Two $\mathrm{DH}$ populations were derived from $\mathrm{F} 1$ hybrids resulting from reciprocal crosses between cv. Californium and DH line W-15. A statistical analysis of both populations, based on two years of experiments, revealed that the greatest variability was characteristic of the number of pods per plant, while the lowest characterized the fat and oleic acid content. The seed yield was positively correlated with the number of branches and the number of pods per plant, while negatively correlated with a thousand seed weight.

Yellow-seeded oilseed rape is a very important source of protein-rich meal for livestock feed. However, the introduction of a yellow seediness trait to oilseed rape results in a reduction in yield with lower agronomic performance. Therefore, it is necessary to improve yellow-seeded breeding materials by further crossing with high yielding black-seeded forms. Hence, the main goal of the studies, conducted for two DH populations derived from F1 hybrids resulting from reciprocal crosses between black- and yellow-seeded DH lines, was to estimate the diversity of DH lines as well as the selection of the best yellow-seeded genotypes. The study indicated the presence of a substantial genetic variability among the $\mathrm{DH}$ lines obtained from $\mathrm{F} 1$ hybrids of crosses between black-seeded and yellow-seeded DH lines. The greatest variability was recorded for seed color and yield (Szała, 2012).

\section{Effects of the cross direction}

The determination of the influence of the cytoplasmic and nuclear genetic maternal effects or the embryo effects for given traits allows to select the appropriate direction of crossing. The reciprocal $\mathrm{DH}$ populations are great material to examine the influence of the direction of the crossing on the expression of the studied traits. A method of contrasts can be used to compare the average values for traits between these populations.

From a two-year field experiment, an estimation was made on the effect of the crossing on yield, its components, and some biochemical characteristics (Szała et al., 2015). The experimental material consisted of two $\mathrm{DH}$ populations obtained from $\mathrm{F} 1$ hybrids of reciprocal cros- 
Table 1. DH line of winter oilseed rape as a material for genetic and statistical studies - summary

\begin{tabular}{|c|c|c|c|}
\hline \multicolumn{2}{|c|}{ Material } & \multirow{2}{*}{ Objective of research } & \multirow{2}{*}{ Reference } \\
\hline Origin & No. of DH lines & & \\
\hline \multirow{5}{*}{$\begin{array}{l}\text { F1 hybrid } \\
\text { DH C-1041 } \times \text { DH O-120 }\end{array}$} & \multirow{5}{*}{32} & $\begin{array}{l}\text { genetic parameters for yield } \\
\text { components }\end{array}$ & Adamska et al. (2002) \\
\hline & & genetic parameters for fatty acids & Cegielska-Taras et al. (2005) \\
\hline & & $\begin{array}{l}\text { genotype-environment interaction } \\
\text { for yield component }\end{array}$ & Cegielska-Taras et al. (2007) \\
\hline & & $\begin{array}{l}\text { genotype-environment interaction } \\
\text { for fatty acids composition }\end{array}$ & Kaczmarek et al. (2008) \\
\hline & & multivariate evaluation & $\begin{array}{l}\text { Adamska et al. (2004) } \\
\text { Kaczmarek et al. (2005) }\end{array}$ \\
\hline \multirow{4}{*}{$\begin{array}{l}\text { F1 hybrids } \\
\text { cv. Californium } \times \text { DH W-15 } \\
\text { DH W-15 } \times \text { cv. Californium }\end{array}$} & 210 & transgression effects & $\begin{array}{l}\text { Kaczmarek et al. (2009) } \\
\text { Szała et al. (2009) }\end{array}$ \\
\hline & \multirow{3}{*}{38} & $\begin{array}{l}\text { genetic variability, } \\
\text { multidimensional analysis } \\
\text { - hierarchical clustering }\end{array}$ & Szała et al. (2013) \\
\hline & & cross direction effects & Szała et al. (2015) \\
\hline & & genotype-environment interaction & Szała (2012) \\
\hline \multirow{3}{*}{$\begin{array}{l}\text { F1 hybrids } \\
\text { DH Z-114 × } \mathrm{DH} \mathrm{H}_{2}-26 \\
\mathrm{DH} \mathrm{H}_{2}-26 \times \mathrm{DH} \mathrm{Z}^{2}-114\end{array}$} & 176 & transgression effects & Szała et al. (2011) \\
\hline & \multirow[t]{2}{*}{44} & genetic variability & Szała (2012) \\
\hline & & cross direction effects & Szała (2012) \\
\hline \multirow{5}{*}{ Different } & \multirow{5}{*}{$\begin{array}{l}7 \mathrm{DH} \text { as a lines } \\
3 \mathrm{DH} \text { as a testers }\end{array}$} & $\begin{array}{l}\text { multidimensional GCA and SCA effects } \\
\text { for yield components }\end{array}$ & Adamska et al. (2007) \\
\hline & & $\begin{array}{l}\text { GCA and SCA effects for fatty acids } \\
\text { content }\end{array}$ & Adamska et al. (2008) \\
\hline & & $\begin{array}{l}\text { genetic distance and GCA } \\
\text { and SCA effects }\end{array}$ & Szała et al. (2009) \\
\hline & & $\begin{array}{l}\text { genotype-environment interaction } \\
\text { for unsaturated fatty acid content }\end{array}$ & Kaczmarek et al. (2011) \\
\hline & & $\begin{array}{l}\text { multidimensional GCA and SCA effects } \\
\text { for yield components }\end{array}$ & Adamska and al. (2007) \\
\hline cv. Bor & 100 & genetic variability & Szała et al. (2002) \\
\hline $\begin{array}{l}\text { F1 hybrid } \\
\text { DH ER-13/1 × JN-86 }\end{array}$ & 300 & genetic variability & Szała et al. (2003) \\
\hline F3 hybrid 3859/86 & 8 & genotype-environment interaction & Adamska et al. (2000) \\
\hline
\end{tabular}

ses between cv. Californium and DH W-15 line derived from cv. Wotan, and the parental forms. In order to conduct such estimation, notice had to be taken of the significant variation between parental forms in the trait and the fact that the basis for inferences about the influence of maternal or paternal effects was the statistically significant differences between the mean values of the $\mathrm{DH}$ lines of the two populations. Both, the pair of parental forms and the pair of $\mathrm{DH}$ line populations revealed significant differences in the number of seeds per pod, and linolenic acid. Maternal effects have been revealed only for the number of seeds per pod.

A method of contrasts was used to compare the average values for seed color, yield components, and seed 
quality between two populations of winter oilseed rape obtained from $\mathrm{F} 1$ hybrids of reciprocal crosses between the black-seeded $\mathrm{DH}$ line $\mathrm{H}_{2}-26$ and the yellow-seeded DH line Z-114, and the parental forms. DH line Z-114 was obtained from a cross segregating for seed color between a natural mutant with bright seeds and a spring line of $B$. napus. The maternal effects were revealed in DH line populations only for the thousand seed weight. In contrast, the influence of the paternal form was found in terms of the content of neutral and acid fiber and seed color (Szała, 2012).

\section{Genotype-environment interactions}

In the breeding of new varieties, the selection for crossbreeding of appropriate parental components with high hereditary agricultural stability plays an important role. The desired properties do not only depend on the genotype, but also on different genotype responses to the environmental factors. Hence, more and more importance is being attached to the assessment of the yield stability and adaptability of new genotypes in different environments. Stable lines, characterized by broad adaptation to different climate and soil conditions, are particularly appreciated. However, genotypes that are narrowly adapted to specific environmental conditions, but which nonetheless show a true yield, are also sought. The first detailed analysis of a genotype-environment $(\mathrm{G} \times \mathrm{E})$ interaction in seed yield of $\mathrm{DH}$ lines of winter oilseed rape was carried out for $8 \mathrm{DH}$ lines, derived from anther culture of F3 hybrid and cv. Mar as a control, and based on the data from a series of experiments conducted at five locations for two years (Adamska et al., 2000). The experimental results were analyzed using uni- and multi-dimensional statistical methods that allowed an evaluation of the $\mathrm{DH}$ lines tested in terms of the amount of yield, and considering different aspects of their interactions with the environment.

An analysis of the interactions of the various genotypes with the environment using linear regression made it possible to distinguish two high seed-yielding DH lines: stable (C-1168) and unstable (C-1074). A similar analysis of the interactions of 38 winter oilseed rape $\mathrm{DH}$ lines derived from $\mathrm{F} 1$ hybrids and their parental forms with environment as well as yield stability assessment were conducted from results obtained over three growing seasons. It was found that the four highest yiel- ding $\mathrm{DH}$ lines showed no interaction with the environment, and, of the six lines sensitive to environmental changes, three lines were defined as intense (Szała et al., 2011).

The other experiments were conducted with $32 \mathrm{DHs}$ of winter oilseed rape, their parental forms, F2 and F3 segregating generations and the standard cv. Kana in six environments. This procedure enabled to determine the environmental and $\mathrm{G} \times \mathrm{E}$ interaction effects on some yield components and the fatty acid content. A statistical analysis of the results made it possible to evaluate $\mathrm{DH}$ lines in terms of different aspects of their environmental interactions for the length of the pod, the number of seeds per pod, and the thousand seed weight. It was also possible to distinguish a group of the best $\mathrm{DH}$ lines with respect to all the studied traits and to differentiate the stable DH lines for these traits and DH lines which showed a significant interaction with the environment (Cegielska-Taras et al., 2007). Using uni- and multivariate statistical methods, DH lines were also estimated under various environmental conditions in terms of the content and stability of two different fatty acid compositions. Kaczmarek et al. (2008) recommended using a model of variance analysis and related statistical methods to evaluate and select genotypes for industrial purposes. A total of 14 genotypes were found acceptable (11 stable and 3 unstable) for the chemical industry and 10 genotypes were acceptable ( 6 stable and 4 unstable) for the biodiesel industry. One $\mathrm{DH}$ line proved to be particularly interesting as it had a very high and significant content of the sum of linoleic and linolenic fatty acid and, simultaneously, a significantly high main effect for seed yield. The line was stable and may be recommended for the use in the chemical industry. The other stable $\mathrm{DH}$ line revealed, simultaneously, higher contents of oleic and lower content of linolenic fatty acids than the mean of all studied genotypes with a very high seed yield. There was a significant difference in the levels between these two fatty acids because this $\mathrm{DH}$ line meets the requirements of the biodiesel industry.

Likewise, $28 \mathrm{~F} 2$ hybrids obtained by crossing seven lines and four testers in the line $\times$ tester mating design, formed the experimental material in three-year series of experiments. The goal of these experiments was the evaluation of the stability of combining ability for unsaturated fatty acid content. Statistical methods made it possible to find two lines and one tester where GCA proved 
to be high in the case of oleic acid and low in the case of linolenic acid (HOLL), i.e. having properties that are advantageous for biodiesel production. It should be added that the general combining ability of one of these lines was insensitive to the environmental conditions, whereas high significant interactions between genotype and year were found for GCA effect for the oleic acid content of a second line and tester (Kaczmarek et al., 2011).

\section{Multidimensional analysis}

The breeding programs of many plant species have aimed at improving of a number of traits that comprise the aspect of productivity and the quality of the crop. The starting materials are thus evaluated for many traits at the early stages of the plant breeding process. Multivariate statistical methods provide a comprehensive assessment of breeding lines while considering many important agronomic characteristics. They also allow for the separation of groups of similar genotypes in respect to many traits as well as the identification of groups of varieties of high value.

In a study of oilseed rape, multivariate statistical methods have been applied by Adamska et al. (2004). They identified genotypes with improved levels of oleic acid and characterized by the ratio of linoleic acid to linolenic acid 2:1 and the saturated fatty acid content of less than $7 \%$, thus fulfilling the three basic criteria for wholesome edible oil. Kaczmarek et al. (2005) evaluated the DH lines in terms of the content of five fatty acids, further Adamska et al. (2007) evaluated the combining ability of $\mathrm{DH}$ lines in terms of the yield components and fat content.

In a multivariate analysis, the Mahalanobis distance is used as a measure of similarity between two objects. Based on the Mahalanobis distance, the hierarchical clustering was performed using the Ward method (Ward 1963) to classify the studied DH lines in terms of several traits jointly. A multidimensional analysis of $\mathrm{DH}$ lines and their parental forms showed their high level of diversity but it was not possible to establish a group of genotypes with the best agronomic performance (Szała et al., 2013).

This review of earlier studies has confirmed numerous possibilities of using winter oilseed rape DH lines in a statistical study. Owing to their genetic stability, $\mathrm{DH}$ lines can be tested in a series of experiments over many years, which allows for efficient selection of desired genotypes and their examination for adaptation in various environments.

\section{Acknowledgements}

This work was partially supported by the Ministry of Agriculture and Rural Development, Poland Project HORhn No 47.

\section{References}

Adamska E., Cegielska-Taras T., Kaczmarek Z. (2000) The analysis of chosen rape DH line on the basis of two year serirs of experiments. Biul. IHAR 216(2): 469-476 (in Polish).

Adamska E., Cegielska-Taras T., Szała L. (2002) The genetic parameters for determining traits of yield elements and the oil contents in oilseed rape estimated on the basis of $D H$ lines obtained from $F_{1}$ hybrid (DH O-120 × DH C-1041). Rośl. Oleiste - Oilseed Crops 23: 215-221 (in Polish).

Adamska E., Cegielska-Taras T., Kaczmarek Z., Szała L. (2004) Multivariate approach to evaluating the fatty acid composition of seed oil in a doubled haploid population of winter oilseed rape (Brassica napus L.). J. Appl. Genet. 45: 419-425.

Adamska E., Cegielska-Taras T., Szała L., Kaczmarek Z. (2007) Multidimensional GCA and SCA effects in doubled haploid lines of winter oilseed rape in the analysis of yield structure characteristics and oil content of $F_{1}$ line $\times$ tester crosses. Rośl. Oleiste - Oilseed Crops 28: 97-108.

Adamska E., Kaczmarek Z., Szała L., Cegielska-Taras T. (2008) Analysis of combining ability of winter oilseed rape DH lines in regard of the contents of fatty acids. Biul. IHAR 249: 177-182 (in Polish).

Cegielska-Taras T., Adamska E., Kaczmarek Z., Szała L. (2007) Response of components of double haploids seed field of winter oilseed rape (Brassica napus $L$.) to diverse environments. Rośl. Oleiste - Oilseed Crops 28: 85-96.

Cegielska-Taras T., Adamska E., Szała L., Kaczmarek Z. (2005) Estimation of the genetic parameters for fatty acid content in DH lines obtained from winter oilseed rape of $F_{1}$ hybrid (DHO120 × DH C-1041). Rośl. Oleiste - Oilseed Crops 26: 11-17.

Kaczmarek Z., Adamska E., Cegielska-Taras T., Szała L. (2005) Multivariate statistical methods used for evaluation of DH lines of winter oilseed rape account of various fatty acid compositions. Rośl. Oleiste - Oilseed Crops 26(2): 325-334.

Kaczmarek Z., Adamska E., Cegielska-Taras T., Szala L. (2008) The use of statistical methods to evaluate winter oilseed rape doubled haploids for industrial purposes. Industr. Crops Prod. 27: 348-353.

Kaczmarek Z., Adamska E., Szala L., Cegielska-Taras T. (2011) Stability of combining ability for unsaturated fatty acids content in $\mathrm{DH}$ lines of winter oilseed rape. Biul. IHAR 260-261: 301-308 (in Polish). 
Kuczyńska A., Surma M., Kaczmarek Z., Adamski T. (2007) Relationship between phenotypic and genetic diversity of parentalgenotypes and frequency of transgression effects in barley (Hordeum vulgare L.). Plant Breed. 126: 361368.

Mahalanobis P.C. (1936) On generalized distance in statistics. Proc. Nat. Inst. Sci. India 2: 49-56.

Szała L. (2012) Phenotypic and genetic variability of the doubled haploid populations of winter oilseed rape (Brassica napus L.). Unpublished $\mathrm{PhD}$ thesis in Polish. IHAR-PIB, Poznań.

Szała L., Cegielska-Taras T., Adamska E., Kaczmarek Z. (2015) Genetic effects on agronomic and seed quality traits in reciprocal $D H$ populations of winter oilseed rape. Jökull (in press).

Szała L., Cegielska-Taras T., Kaczmarek Z., Adamska E. (2013) Variability of some quantitative traits in DH line population of winter oilseed rape obtained from $F_{1}$ hybrids of reciprocal crosses. Rośl. Oleiste - Oilseed Crops 34: 167-186 (in Polish).

Szała L., Kaczmarek Z., Adamska E, Cegielska-Taras T. (2009a) Effects of transgression in DH line populations of winter oilseed rape (Brasica napus L.) obtained from $F_{1}$ hybrids of reciprocal cross $\mathrm{cv}$. Californium and $\mathrm{DH} \mathrm{W}-15$. Rośliny Oleiste - Oilseed Crops 30(2): 185-196 (in Polish).
Szała L., Kaczmarek Z., Cegielska-Taras T., Adamska E. (2011) Influence of yellow-seeded parent on DH populations of Brassica napus obtained from reciprocal crosses between black-and yellow-seeded DH line. Proceedings $13^{\text {th }}$ International Rapeseed Congress, Prague, Czech Republic, CD Abstract Books.

Szała L., Krótka K., Cegielska-Taras T. (2002) The characteristic of doubled haploids obtained from cultivar Bor of winter oilseed rape. Rośl. Oleiste - Oilseed Crops 23: 243254 (in Polish).

Szała L., Krzymański J., Wójtowicz M., Cegielska-Taras T. (2003) The phenotypic variation in the population of doubled haploid lines obtained from $F_{1}$ hybrid generation of winter oilseed rape (Brassica napus L.). Rośl. Oleiste - Oilseed Crops 24(2): 355-364 (in Polish).

Szała L., Olejnik A., Adamska E., Kaczmarek Z., CegielskaTaras T. (2009b) Genetic and phenotypic diversity of parental forms of winter oilseed rape (Brassica napus L.) on the basis of line $x$ tester experiment. [In:] Genetyka i genomika $w$ doskonaleniu roślin uprawnych. Ed. B. Naganowska, P. Kachlicki, P. Krajewski. Inst. Genet. Rośl. PAN w Poznaniu: 239-245 (in Polish).

Ward J.H. (1963) Hierarchical grouping to optimize an objective function. J. Amer. Stat. Assoc. 58: 236-244. 